\title{
Rea, K. (2013): the healing dance - the life and practice of an expressive arts therapist: Springfield, ILL: Charles C. Thomas
}

\author{
Esme Joanna Jaaniste
}

\section{Book review by Esme Joanna Jaaniste, PhD Candidate and Arts Therapist, University of Western Sydney}

This book presents the reader with a journey which every expressive Arts therapist must take in one form or another if they want to work with clients who have come with deep life questions. Kathleen Rea's own experience as a dancer has led her to write of her struggles with childhood abuse, followed by a career in ballet where she received daily pressure to achieve bodily conformity and perfectionism. Along with many who choose ballet as their profession, Rea was given strong messages that her body was unable to meet the standards set by the art form, together with mandatory dieting. Presenting her with an added burden to her early sexual abuse, her situation resulted in anorexia, bulimia and prodromal violent self-harm.

Rea eventually found an eating disorder therapist and began to learn about the sound of her true voice. Eventually, she ceased dieting and sought improvisational dance. Watching untrained people move, with "unfiltered expression" rather than technical skill, she felt humbled, realising that authentic embodied soul presence was showing her a "way home". She began to let go and learn to play, gradually transitioning towards a new way of being. Her favourite teacher when she joined an expressive arts therapies MA course was a wounded healer who recognised Rea's own journey towards becoming a therapist. He showed her how to recognise transformation based on compassion and love rather than crisis and willpower. Not long afterwards, she "arrived home", realising that she was indeed a therapist.

Rea describes the choreography experience that had led her to a deeper knowledge of body-based wisdom,

Correspondence: dramatherapy@ozemail.com.au

Department of Social Sciences and Psychology, University of Western

Sydney, Room 37, Ground Floor, Building 1, Bankstown Campus, Locked Bag 2751, NSW 2751, Penrith, Australia self in relation to the world and wellness versus dysfunction. She bases her three-part working map on these foundations, explaining the separate experiential steps in each part. The Body Wisdom map, for example, is made up of the experiences of action, physiology, imagination and thought, emotion and spirit and she explores each in detail. For the map of Self in Relation to the World, she provides a fragment of a case study of Allen. The reader will meet Allen many times over the course of the book, but here Rea describes the awkwardness of his first vist and the disconnect between his own life and the world he lives in. He is grossly overweight, yet no one mentions it, and he wants to stop pretending. The Wellness and Dysfunction map continues by exploring Allen's unwellness of being, and includes the dysfunctional patterns that Rea has observed in people with eating disorders. These challenges are in the areas of connection, fragmentation, rejected aspects of self and self-harming.

In the book's longest chapter, entitled "Healing through the Arts", Rea documents the journey she takes with Allen. Surprisingly, the art of dance features very little here. She works with small movements and sound, with drawing, 3D sculpture, writing, drama, poetry and song. She explains to the reader as she goes how the arts build relationships and make connections with the world. As a therapist, she allows herself to be led by the client, witnessing big and small changes and re-framing where necessary in a safe environment. The phenomenological approach to her client is intertwined with her explanations of the various facets of the therapy as the sessions progress. The core of the therapy is to allow Allen to return disassociated feelings and thoughts to his body and to understand the meaning of his pain. The final session involves an expression of Allen's gratitude that Rea never mentioned losing weight over the two years she worked with him. 
In the remainder of the book, the author revisits a self- and ensemble-devised piece called Long Live which helps her through her father's death. She explores grief as an art, and here dance movement therapy comes into its own. Once again, Rea is back with her own life experience and the mixed feelings that come with finding a partner, pregnancy and losing a father. Snippets of case studies enter in occasionally; however body movement as a way of expressing deep grieving is paramount in the unfolding of the story of her own grief and exploring the relationship with her father, with whom there was often confrontation, now healed.

The final chapter consolidates some of the ideas mentioned earlier in the book, when she explains how she works with a six-step method of inner body sensation and the arts. Basically, she asks the client to notice the sensation, describe it, stay with it, find a shape or movement that matches it, amplify and intensify it and then harvest the richness received by turning towards it rather than denying it. Allen's experience had been to find out his "monster" was not a monster at all, "but a part of (him) that wants to be acknowledged and allowed to come home". These gentle steps can allow the client to come to understand that disassociated emotions can gradually be understood and owned rather than discarded or suppressed. She correlates her six step method with the forms of body wisdom described earlier in the book.

If the reader is seeking strict methodological guidelines on expressive Arts therapy with clients who have an eating disorder, this is not their territory. However, if the enquirer wishes to learn about simple, well-trodden steps in the evolving practice of a self-aware expressive Arts therapist sharing her knowledge and experience in a demanding area of specialisation, it is a truly heartwarming and satisfying read.

\section{Competing interests}

The author declares that she has no competing interests.

\section{Acknowledgements}

Acknowledgements are due to Professor Philippa Hay, Foundation Chair of Mental Health School of Medicine \& Centre for Health Research, University of Western Sydney for the opportunity to contribute to this journal.

Received: 10 June 2013 Accepted: 11 June 2013 Published: 8 August 2013

doi:10.1186/2050-2974-1-25

Cite this article as: Jaaniste: Rea, K. (2013): the healing dance - the life and practice of an expressive arts therapist: Springfield, ILL: Charles C. Thomas. Journal of Eating Disorders 2013 1:25

\section{Submit your next manuscript to BioMed Central and take full advantage of:}

- Convenient online submission

- Thorough peer review

- No space constraints or color figure charges

- Immediate publication on acceptance

- Inclusion in PubMed, CAS, Scopus and Google Scholar

- Research which is freely available for redistribution 